\title{
Research of innovation activity influence on return of stocks in industrial enterprises
}

\section{Gaziyev Obidjon}

Accountant, Department of Finance and Accounting, GM-Uzbekistan, Andijan, Uzbekistan

\section{Oleksii Zakharkin}

Ph.D. in Economics, Associate Professor, Department of Finance and Credit, Institute FEM named after Oleg Balytskiy, Sumy State University, Ukraine

\section{Liudmyla Zakharkina}

Ph.D. in Economics, Associate Professor, Department of Finance and Credit, Institute FEM named after Oleg Balytskiy, Sumy State University, Ukraine

\begin{abstract}
The paper investigates the possibility of using the Fama-French Three Factor Model to determine the effect of innovation on the market value of the enterprise's securities, and the regulation of index that characterizes excessive equity returns is proposed to register. The structure of determinated influencing factor to model the connection of innovation and market value of the enterprise's securities was fixed. The methods of calculating the parameters which are the part of the Fama-French Model are given considering their adaptation to the economic conditions of developing countries. The indicators of innovation activity of enterprises, the index of economic development and innovation of the country are proposed to use as a variable component of the model. With the help of software complex Stata 12 the results of structural modeling impact of the innovations on the characteristics of profitableness and risk in assessing the market value of securities of Ukrainian enterprises are received.
\end{abstract}

Keywords: innovations, return on equity, modeling, risks, innovative activity, industrial enterprises.

JEL Classification: O31, D24, L25, C51.

DOI: $10.21272 / \mathrm{sec} .1(2) .80-102.2017$.

(C) The Authors, 2017. This article is published with open access at ARMG Publishing.

\section{Introduction}

Many researches consider the implementation of innovative activity by enterprise to be a factor of formation its competitive advantages both at the commodity and capital markets. Actually, the innovative activity of enterprise for many investors is a signal that it can be more successful and profitable comparatively with competitors and therefore can be a better way to invest. Successful realization of innovative projects by the enterprise positively effects key index of its effectiveness, providing the creation of extra-value and heightening the level of capitalization of the enterprise. Innovations may be considered as a ponderable factor to increase the value of the enterprise for each group of stakeholders - workers, owners, consumers and society on the whole. Valuation of extra-value for every mentioned stakeholder's group is accomplished according to different criterion and index. The modern theory of economy considers owners or shareholders as the main enterprise stakeholders which are interested in the building-up its value. The growth of value owing to innovative activity for them should find its reflection in the upturn of profitability of stocks, dividend outcome and the increase of market value of stocks of the company.

However, as practice attests, innovative enterprise activity not always correlates with accretion to the actions. First of all, it is connected with the fact, that the considerable amount of another financional and nonfinancional factors in addition to innovations influence on forming the rate of exchange compaigh actions. Besides, share markets of many countries are different, because of standard level, peculiarities of their functioning, and they are characterized by different reactions of depositors on factor of innovative enterprise activity. Consequently, the realization of innovative enterprise activity does not mean reinforcement of it's competitiveness at the open market. That is why within the framework of consideration of value-oriented 
approach to management of innovative enterprise activity, it is necessary to investigate how much "costly" innovative activity is in the eyes of shareholders and if it guarantees an increase of market value and capital gam on corporate issues and what impact has the grade and nature of the effect innovations on enterprise stock value. According to the example of Ukrainian stock market, providing an investigation of interconnection between innovative enterprise activity criterion and value market of its actions is actual nowadays.

\section{Literature review}

Generally, foreign researchers' approaches to characteristics of the innovations' role in creating the additional value for investors can be divided into three main types. The first group of scientists believes that innovations have a positive impact on the course price for company shares. Thus, in the works of Bowman D., Gatignon H. (2009), Hall B.H., and Oriani R. (2006), the increase of shares' yield takes place because the implementation of product and technological innovations takes time for their duplication by competitors, within which innovationally active enterprises can get greater income.

Another aspect of the positive role of innovations, as it is noted by McAlister L., Srinivasan R., and Kim M. (2007), is to promote the company to reduce the tendency of systematic risk as a result of providing a more flexible response to changing market demands and economic situations in general.

Such researchers as Lantz J.-S. and Sahut J.-M. (2005) have an opposite attitude, they think that innovation activity intensifies the ambiguity of the enterprise activity, increasing non-systemic risk and its lameness to the negative influence of systemic risks.

Excellent grades of scientists also deal with interconnection of innovations and return on equity. For instance, Chan L.K.S., Lakonishok J. and Sougiannis T. (2001) have established that in long-term outlook those revenues which were received from innovation corporate securities, equalize with the data of price ratio of the enterprises that do not implement innovations.

Another group of scientists - Kothari S., Lagguere T. and Leone A. (2002) - takes the view that innovations are characterized by a high level of risk, the amount of unsuccessful innovation projects is very generous and it does not change during the time, that is why risks which are connected with this activity, out-weight possible benefits, reducing investors' interest in accordant investments. According to this, researchers make conclusion about the existence of correction retraction between the return on equity of the company and the amount of its innovation expenses. Simultaneously, innovations are capable of increasing idiosyncratic risk which is connected with the activity of a certain enterprise, because the forecastability of its future inpayments reduces.

Analyzing the results of scientists study concerning the identification of the relation between innovations and rate of expected return and the risk of investing in securities, authors can point out the presence of rather contradictory results. As follows, the real nature of innovation impact on mentioned rates is not the only possible and can be estimated in terms of specific operation conditions of the enterprise and macroeconomic, legal, industry factors. So, the researchers point out that the reaction of stock market participant on innovative activities of business entities rather varies in different countries (Ngobo P.V., Gatignon H., 2012).

Considering the multidimensionality and ambiguity of interconnection between innovative activities of enterprise and satisfaction of interests of the main group of its stakeholders that are the owners in the context of value-oriented management, there is a need of operating an economic and mathematical model needed for depicting the dependence of market value change of the company share capital by implementation of innovative activity in different operating conditions and influence of external factors. For the purpose of working out economic and mathematical model of dependence of competitor position of the company on securities market (that is estimated by a market value change of its shares and degree of development) from the level of its innovative activity, it is useful to review first of all main scientific and methodological approaches for securities modeling in the stock market formed for today. The basis for advanced models of yield capital asset pricing is developed by V. Sharp $(1964,1970)$ and J. Lintner (1965) capital asset pricing model. For the description of the formation of the expected yield of financial assets analysts used the sum of two components: riskless interest rate and the risk premium of the asset.

The characteristic feature of this model is the consideration of only one source of risk - a systemic risk, the value of which is measured by $\beta$ coefficient. Thus, unsystematic risks are not considered in the model, as it is believed that they can be eliminated through portfolio diversification (Hubbard R. Glenn, 2004). 
Later, the presence of many assumptions and shortcomings of the model CAPM led to its revision by many researchers and appearance of new models of yield capital asset pricing model on its basis (Ross S.A., 1977, Mossin J., 1966, Tobin J., 1965, Black F. and Sholes M., 1974).

Attempts to take into account the greater number of risks that affect the expected return of securities contributed to the development of multifactorial capital asset pricing model. Thus, according to the arbitration theory developed by S. Ross, different macroindicators may become sources of systemic risk. It is necessary to calculate $\beta$ coefficient for each of them as a sensitivity indicator of expected yield to change a corresponding factor (Ross S.A., 1977).

Another group of researchers emphasizes the need to incorporat specific non-systemic risks except systemic risks. So it is proposed to calculate the expected profitableness depending on the influence of market using Fama-French Three-Factor Model (1996). In other words, it is necessary to take into account the systemic risk as the difference between profitableness of market portfolio and the risk-free rate or premiums for size, as the difference between profitableness of securities portfolios of companies with low and large capitalization and premiums for price - characteristics that reflect the difference between the profitableness of the securities portfolio of small and large correlation value between market and book value. A corresponding sensitivity coefficient $\beta$ is applied for each of these components.

To ensure high reliability of prediction of securities portfolio's profitability indexes, M. Cahart proposed to supplement the Fama-French Three-Factor Model with the fourth factor - a factor of price momentum, that characterized the difference between the income of security portfolio, on which during last period (6 month) it was seen the increase in its (price's) market value, and income of security portfolio, that was characterized by decline in value (Carhart M.M., 1997).

Among modern Ukrainian scientists, who deals with the problems of valuation and modeling of the profitableness of securities, may be noted V.V. Vitlinskiy, H.I. Velykoivanenko (2004), A.B. Kaminskiy (2007) and other researchers.

However, existing models fail to account for the effects of innovation on the profitability of the enterprise securities, which requires further improvement and adaptation to modern conditions of economic development.

\section{Methodology and findings}

The information basis for the implementation of the proposed scientific and methodological approach to the study of the effect of innovation on the assessment of the market value of shares were made by the financial statements and performance of the exchange securities trading for 2011-2013 of the following companies in the chemical and machine-building industry of Ukraine: PJSC Avdiivka Coke Plant, PJSC Concern Stirol, PJSC Stakhanov Carbon Black Plant, PJSC Jasynivsky Chemical-Recovery Plant, PJSC Dniprovsky Machine-Building Plant, PJSC Dniprovagonmash, PJSC Ukrainian's Granitic Industry, PJSC Khartsyzsk Pipe Plant, PJSC Kryukovsky Railway Car Building Works, PJSC Luganskteplovoz, and PJSC Pantec, and PJSC Stakhanovsky Railway Car Building Works.

The choice of the research objects was held among enterprises of chemical and machine-building industries that belong to the public joint-stock companies and according to their shares the real exchange trades in the PFTS (First Stock Trading System) were realized during 2011-2013 and the stock exchange price became fixed. The period of research depends on the available data about results of exchange trades of enterprises securities in the PFTS.

At the first stage of realization of scientific-methodological approach to impact assessment of innovations on the competitive position of the company on the stock market, it is necessary to calculate indexes of excess profitableness of securities $(A R)$ and parameters that characterised systematic $(S R)$ and idiosyncratic risks $(I R)$ for each of researched enterprises in each of periods analyzed (2011-2013). For this purpose, it is reasonable to use the three-factorial model of Fama-French (Fama E.F., French K.R., 1996).

Based on the goal of research, the advantages of this model are the following:

1. Taking into account more factors, the model of Fama-French allows us to model the process of price fixing in the stock market more accurately: risks the appearance of which is exclusively connected with innovative activity of the enterprise, and relate to specific (idiosyncratic) risks of the company, and that is why they can not be taken into consideration during the analysis of systematic (market) risksonly. 
2. This model allows calculating the possibility of diversified innovations influence on different risks, and consequently, their reflection both in increaseand in decrease of market value of stocks.

3. Additional criterion, implemented in the Fam-French Model, allow to consider the industry specialization of the company, that has a critical value during researching the innovating activity of enterprise, ias the depending of its belonging to the hi-tech or low-tech industries, the needed total of investments, the expected results from innovations and the liability of implementations of innovations over all are evaluated.

In general terms Three-Factorial Fama-French Model can be presented as the equation (Fama E.F., French K.R., 1996):

$$
r_{i}=\gamma_{i}+\beta_{i 1}\left(r_{m}-r_{f}\right)+\beta_{i 2} r_{S M B}+\beta_{i 3} r_{H M L}+\varepsilon_{i},
$$

Where $r_{i}$ - return on $i$ asset; $\gamma_{i}$ - expected return on $i$ asset without the influence of definite risks on it; $r_{m}-$ returns of the market (as a whole); $r_{f}$ - risk-free rate; $r_{S M B}$ - spread between the returns of middle weighted returns on assets of companies with small and large capitalization; $r_{H M L}-$ spread between the returns of middle weighted returns on assets of companies with high and low correlations of balance costs to the market ones; $\beta_{i 1}, \beta_{i 2}, \beta_{i 3}$ - indexes, that characterize the influence according to the measures to return on $i$ asset; $\varepsilon_{i}$ - blunder.

To estimate the system and idiosyncratic risks in the Fama-French Model, the regressive indexes $\beta_{i}$ are used, which show the relation of the company's stock profitability to the general level of securities profitability in the stock market, in view of each experimental variable.

On the next step of economic-mathematical model development, using three factor characteristics as dependent variables - stock profitability, system and idiosyncratic risks identified in the Fama-French Model, it is necessary to perform a formalization of the influence of innovative activity of the company on each of them.

The model is based on the assumption that investors react on innovative activity of the company in accordance with expected accretion of pure actual cash flow cost, created as a result of this activity. Thus, index, which characterizes the level of innovative activity of the company in the suggested scientificmethodological approach, is the only factor characteristic.

According to the results of the research about peculiarities of the influence of innovation on accretion of business cost depending on created macroeconomic, lawful, social and other conditions, likewise the level of the innovation of country's economy in general, for adequate reflection of interconnections between innovative activity of the company and investigated parameters of profitability and riskiness of its stock, it is necessary to add the group of additional parameters and control variables to smooth the effects after branch peculiarities of the company, its rate and scale of activity, etc.

Thus, according to suggested approach, the totality of determinate parameters to model the influence of innovative activity on the valuation of company's stock cost can be represented in the following Table 1 .

Table 1. The consistency of determined factors that influence the modeling of connections between innovations and market value of enterprise securities

\begin{tabular}{|c|c|c|}
\hline Variable & Indicator & Economic content \\
\hline \multicolumn{3}{|r|}{ Dependent variables } \\
\hline$A R$ & $\begin{array}{l}\text { Extra return on } \\
\text { shares }\end{array}$ & $\begin{array}{l}\text { The level of deviation of real return on shares of the enterprise from the rated level. Under condi- } \\
\text { tions of the effective market the indicator should be } 0 \text {, its deviation states that the market mem- } \\
\text { bers "underrate" or "overrate" the shares of the enterprise. }\end{array}$ \\
\hline$S R$ & Systemic risk & $\begin{array}{l}\text { It characterizes the deviation of the return on shares under the influence of general market factors } \\
\text { and is calculated according to the indicator of the stock market of each separate country. }\end{array}$ \\
\hline$I R$ & $\begin{array}{l}\text { Idiosyncratic (non- } \\
\text { systemical) risk }\end{array}$ & $\begin{array}{l}\text { It indicates the deviation of profitable shares of the company under the influence of specific } \\
\text { factors, determined by the coefficient with indexes } r_{S M B} \text { and } r_{H M L} \text {. }\end{array}$ \\
\hline \multicolumn{3}{|r|}{ Independent variables (factor feature) } \\
\hline$I A$ & $\begin{array}{l}\text { Innovative activity } \\
\text { of the enterprise }\end{array}$ & $\begin{array}{l}\text { It characterizes the level of innovative activity of the enterprise and is determined by the correla- } \\
\text { tion of the innovative expenses of the enterprise to the total cost of its assets. }\end{array}$ \\
\hline
\end{tabular}


Table 1 (cont.). The consistency of determined factors that influence the modeling of connection between innovations and market value of enterprise securities

\begin{tabular}{|c|c|c|}
\hline Variable & Indicator & Economic content \\
\hline \multicolumn{3}{|r|}{ Additional parameters } \\
\hline $\operatorname{IEF}\left(Z_{1}\right)$ & $\begin{array}{l}\text { Index of eco- } \\
\text { nomic freedom }\end{array}$ & $\begin{array}{l}\text { The index that characterize the general level of enterprise activity freedom and the protec- } \\
\text { tion of investors in the country. }\end{array}$ \\
\hline$G C I\left(Z_{2}\right)$ & $\begin{array}{l}\text { Country } \\
\text { innovation }\end{array}$ & $\begin{array}{l}\text { It is determined as a component of the index of the global competitiveness including the } \\
\text { indicators of innovativeness in economy and technological level of business. }\end{array}$ \\
\hline \multicolumn{3}{|r|}{ Control variables } \\
\hline$R O A\left(Z_{3}\right)$ & $\begin{array}{l}\text { Profitability of } \\
\text { assets }\end{array}$ & $\begin{array}{l}\text { It is an indicator that can be considered by investors during the decisions on buying the } \\
\text { securities of the enterprise. }\end{array}$ \\
\hline Assets $\left(Z_{4}\right)$ & $\begin{array}{l}\text { Total cost of the } \\
\text { assets of the } \\
\text { enterprise }\end{array}$ & $\begin{array}{l}\text { It represents the scales of the enterprise's activity, gives the overall image of its property } \\
\text { base. }\end{array}$ \\
\hline Net sales $\left(Z_{5}\right)$ & $\begin{array}{l}\text { Net profit of } \\
\text { realization }\end{array}$ & $\begin{array}{l}\text { It characterizes the position of the enterprise on the trade market and the scales of its main } \\
\text { activity. }\end{array}$ \\
\hline Employees $\left(Z_{6}\right)$ & $\begin{array}{l}\text { The number of } \\
\text { employees }\end{array}$ & $\begin{array}{l}\text { An additional factor that characterizes the business caliber and the scale of the activity of } \\
\text { the enterprise. }\end{array}$ \\
\hline
\end{tabular}

Source: elaborated by the authors using Economic Research: Fama E.F., French K.R. (1996), Carhart, M.M. (1997).

To evaluate the innovative activity of the enterprise, one can use different indicators that characterize the amount of appropriate expenses - for doing researches and operations, buying patents, making technological renewing, as well as represent the results of innovative activity - the amount of realized innovative production, registered patents, etc.

To adapt this model to the conditions of the stock market of Ukraine, the index excess return, characterizing the level of deviation of real income securities companies from the calculated level, is proposed to use. In the conditions of an efficient market, this indicator should be 0 , deviations from this value indicates that market participants are "underrated" or "overrated" shares of the company. With this aim an additional parameter $\alpha_{i}$ which characterizes the above-level of dividend yield was introduced in Fama-French Model:

$$
r_{i}-r_{f}=\alpha_{i}+\beta_{i 1}\left(r_{m}-r_{f}\right)+\beta_{i 2} r_{S M B}+\beta_{i 3} r_{H M L}+\varepsilon_{i},
$$

It's reasonable to start the calculation of parameters of the Fama-French Model from the determination of indexes of company's dividend yield $r_{i}$ for every second quarter of examining period. In a general case, dividend yield is defined with taking into account the price change of shares and sums of dividends payed for them:

$$
r_{i k}=\frac{\left(P_{i k}-P_{i k-1}+D_{i k}\right)}{P_{i k-1}},
$$

where $P_{i k}$ та $P_{i k-1}$ are stock prices of company's shares and for the end of quarters $k$ and $k-1$ accordingly; $D_{i k}$ is the sum of dividends which company pays for accounting period pending in $k$ quarter.

Taking into account that dividends are not payed for shares of many companies included in the list or data about this are absent, we will make calculation of its profitableness exceptionally taking changes if its exchange prices for appropriate quarter into account (Tables A1 and A2 in Appendix).

As a risk-free rate $r_{f}$ we use activities of profitableness established by exchequer bills (Economic Research, 2011-2013). Market profitability $r_{m}$ must reflect the average level profitableness by securities which were formed in examining stock market. As far as a model of PFTS data is an information bases concerning quotation shares of Ukrainian companies than authors can calculate a market profitability for a required period using the rate of growth of the index PFTS with the formula:

$r_{m k}=\frac{\left(I_{k}-I_{k-1}\right)}{I_{k-1}}$, 
where $I_{k}$ and $I_{k-1}$ are the values of PTFS index at the completion of quarters $k$ and $k-1$ accordingly.

Quarterly values of the risk-free rate and market rate of shares return on PFTS in 2011-2013 are presented in Table 2.

Table 2. Risk-free and market profitableness in 2011-2013

\begin{tabular}{|l|c|c|c|}
\hline \multicolumn{1}{|c|}{ Period } & Risk-free rate $\left(r_{f}\right), \%$ & Index of PFTS $\left(I_{k}\right)$ & Market profitableness $\left(r_{m}\right), \%$ \\
\hline $4^{\text {th }}$ quarter of 2010 & - & 975.08 & - \\
\hline $1^{\text {st }}$ quarter of 2011 & 0.13 & 1099.18 & -18.57 \\
\hline $2^{\text {nd }}$ quarter of 2011 & 0.05 & 895.01 & -37.17 \\
\hline $3^{\text {th }}$ quarter of 2011 & 0.02 & 562.32 & -4.96 \\
\hline $4^{\text {th }}$ quarter of 2011 & 0.01 & 534.43 & -0.52 \\
\hline $1^{\text {st }}$ quarter of 2012 & 0.07 & 531.64 & -31.85 \\
\hline $2^{\text {nd }}$ quarter of 2012 & 0.09 & 362.31 & 1.98 \\
\hline $3^{\text {th }}$ quarter of 2012 & 0.10 & 369.47 & -11.04 \\
\hline $4^{\text {th }}$ quarter of 2012 & 0.09 & 328.69 & -0.02 \\
\hline $1^{\text {st }}$ quarter of 2013 & 0.09 & 328.63 & -5.74 \\
\hline $2^{\text {nd }}$ quarter of 2013 & 0.03 & 309.78 & -3.63 \\
\hline $3^{\text {th }}$ quarter of 2013 & 0.05 & 298.55 & 0.66 \\
\hline $4^{\text {th }}$ quarter of 2013 & 0.06 & 300.53 & \\
\hline
\end{tabular}

Source: elaborated by the authors using Economic Research. 3-Month Treasury Bill: Secondary Market Rate, 2010-2013 and Stock Exchange "PFTS", 2010-2013.

Rate $r_{S M B}$ is defined as the difference in profitableness earned by investors when investing in stocks of companies with relatively low capitalization. The source is the position that investors prefer stocks with high market capitalization as less risky, and the rate $r_{S M B}$ reflects these additional securities in which investors agree to buy stocks with small market capitalization and sell stocks with large capitalization. A positive value $r_{S M B}$ indicates that the profitableness of securities of companies with small capitalization, a negative value, on the contrary, indicates higher stock returns of companies with large capitalization. In its turn, the rate $r_{H M L}$ is the additional profitableness received by investors who invests in companies with a high ratio of book value to market, expecting that their actions will bring more profit. Investors who prefer to purchase such securities, expect an increase in value in the future, in which they are due to changes of exchange. Strategy investors, who prefer stocks with low carrying value and market value (growth shares), are counting on the continued growth of company profits, and corresponding positive expectations of investors. To calculate the components $r_{S M B}$ and $r_{H M L}$, it is necessary to carry out the distribution of all of the investigated enterprises into 6 groups, according to the criteria of market capitalization, book value and market value ratio. The use of first criterion in scientific literature has some differences: the distribution of enterprises into small and big can occur equally 50\%50\% (Ngobo P.V., Gatignon H., 2012) or according the proportion of big and small enterprises 20\%/80\% (Carhart M.M., 1997). Within the framework of this study, taking in account the small sample of enterprises, authors consider the choice of the first approach with equal distribution of enterprises according to the criterion of its market capitalization as the most acceptable. The matrix is used for the distribution of enterprises according to the criteria presented in Table 3.

Table 3. Matrix for calculation of components $r_{S M B}$ and $r_{H M L}$

\begin{tabular}{|l|l|c|c|c|}
\hline \multirow{2}{*}{\multicolumn{2}{|c|}{}} & \multicolumn{3}{|c|}{ Level indicator of book value and market value ratio } \\
\cline { 3 - 5 } \multicolumn{2}{|c|}{} & $\begin{array}{c}\text { Low (L) 30\% } \\
\text { of enterprises }\end{array}$ & $\begin{array}{c}\text { Middle (M) 40\% } \\
\text { of enterprises }\end{array}$ & $\begin{array}{c}\text { High (H) } 30 \% \\
\text { of enterprises }\end{array}$ \\
\hline \multirow{2}{*}{$\begin{array}{l}\text { Market } \\
\text { capitalization }\end{array}$} & Small (S) 50\% of enterprises & SL & SM & SH \\
\cline { 2 - 5 } & Big (B) 50\% of enterprises & BL & BM & BH \\
\hline
\end{tabular}

Source: elaborated by the authors using Economic Research (Ngobo P.V., Gatignon H., 2012).

Market capitalization is defined as the product of the number of shares in circulation and its exchange rate at the respective balance sheet date. The input data and results of calculations are presented in Tables A1, A3, A4 in Appendix. 
The book value of the company while calculating the ratio of the book and market value represents the value of property reduced by its commitments. In this study the value of the company's equity is used, as an index, the results of calculations of the ratio of the book and market values is presented in Table A5 in Appendix.

Analyzing the results of the calculations, it can be noted that some enterprises occupy a stable position both in terms of market capitalization, book and market values. Thus, during the study period, PJSC Avdiivka Coke Plant, PJSC Khartsyzsk Pipe Plant and PJSC Kryukovski Railway Building Workswere assignedto big companies by market capitalization.Under this criterion PJSC Dniprovsky Machine-Building Plant and PJSC Pantec were relatively small businesses in 2011-2015 period.

The situation is more variable in terms of balance value and the market value of Ukrainian enterprises. During the study period PJSC Avdiivka Coke Plant and PJSC Yasynivskyi Coke Plant, can be attributed to the companies with consistently high value of this index and companies PJSC Dniprovagonmash and PJSC Kryukovsky Railway Car Building Works - with a medium value of this index.

The companies having an exceptionally low level of the indicated index are absent. During the investigated period other companies are characterized with changes in comparative valuations of the level of their market capitalization and correlation of the book and market values. In accordance to the results of calculation, the matrices with the distribution of companies under the indices of market capitalization and the correlation of book and market values were formed for every quarter of 2011-2013, and the appropriate meanings of price/earnings ratio for every group of companies during every accounting period are calculated.

At the next step the meaning of $r_{S M B}$ and $r_{H M L}$ indices are directly calculated. The secondary income $r_{S M B}$ ("small minus big") is defined as a difference between the average income of portfolio of shares of companies with a small capitalization and the average income of portfolio of shares of companies with a big capitalization:

$r_{S M B}=\frac{S L+S M+S H}{3}-\frac{B L+B M+B H}{3}$.

In turn, to estimate the $r_{H M L}$ index, we find the difference between the arithmetical mean of portfolio of shares return with a high index of correlation of book and market values, and average of portfolio of shares return in companies with a low level of the book and market values:

$r_{H M L}=\frac{S H+B H}{2}-\frac{S L+B L}{2}$.

The calculation data of the quarterly values $r_{S M B}$ and $r_{H M L}$ for the Ukrainian enterprises of chemical and engineering industries for 2011-2013 period are presented in Table 4.

Table 4. The calculated values of $r_{S M B}$ and $r_{H M L}$ for the investigated enterprises in 2011-2013

\begin{tabular}{|l|c|c|}
\hline \multicolumn{1}{|c|}{ Period } & $\begin{array}{c}\text { A difference in the profitableness of the } \\
\text { stocks of the companies with small and large } \\
\text { capitalization, } r_{S M B} \%\end{array}$ & $\begin{array}{c}\text { A difference in the profitableness of the stocks of } \\
\text { the companies with high and low } \\
\text { balance to market value ratio, } r_{H M L} \%\end{array}$ \\
\hline $1^{\text {st }}$ quarter of 2011 & 2.80 & -1.73 \\
\hline $2^{\text {nd }}$ quarter of 2011 & 18.85 & 4.15 \\
\hline $3^{\text {th }}$ quarter of 2011 & 5.84 & -47.61 \\
\hline $4^{\text {th }}$ quarter of 2011 & 0.90 & 41.37 \\
\hline $1^{\text {st }}$ quarter of 2012 & -10.53 & -32.37 \\
\hline $2^{\text {nd }}$ quarter of 2012 & 26.34 & -13.91 \\
\hline $3^{\text {th }}$ quarter of 2012 & -17.09 & 2.78 \\
\hline $4^{\text {th }}$ quarter of 2012 & 12.05 & 19.16 \\
\hline $1^{\text {st }}$ quarter of 2013 & 56.80 & 78.35 \\
\hline $2^{\text {nd }}$ quarter of 2013 & -1.56 & -2.19 \\
\hline $3^{\text {th }}$ quarter of 2013 & -9.12 & 1.13 \\
\hline $4^{\text {th }}$ quarter of 2013 & 4.81 & -10.39 \\
\hline
\end{tabular}

Source: elaborated by the authors from the data of Tables A.1, A.3, A4 in Appendix.

At the next step of the implementation of proposed scientific-methodical approach, having data on all variables of equations (2), authors conduct its parameterization using the function of linear regression in the software complex Stata 12. Calculations are performed in the context of each company for the three periods 2011, 2012 and 2013, using quarterly data all the variables in the equations for the corresponding year, and if 
necessary, to improve the accuracy of calculations - one contiguous block. The results of the regression analysis are presented in Table A.6 in Appendix.

On the basis of obtained coefficients $\beta_{i}$ of the indicators of system and desecrating risks, as well as the parameters $\alpha_{0}$ (free member of regression equation), authors can construct the Fama-French equation for each of enterprises investigated in 2011, 2012 and 2013. For example, the relationship between the profitableness of stocks, systematic and idiosyncratic risks for PJSC Avdiivka Coke Plant in 2011 can be represented by the following functional dependence:

$$
r_{i}-r_{f}=-11.7797+0.6381\left(r_{m}-r_{f}\right)+0.2578\left(r_{S M B}+r_{H M L}\right) .
$$

From this regression equation we can see, that the level of actual company's stock profitability is directly proportional to the amount of premium, paid for system and idiosyncratic risks. In addition to that, the influence of premium's change for system risk on a fluctuation of company's stock prices, is much more higher than premiums, caused by specific factors. The value of $\alpha_{0}$ equals 11.7797 means that the formation of stock market value fot PJSC Adviivka Coke Plant in 2011 was influenced by other factors, except for system and idiosyncratic risks, investors "underestimated" company's stock and its profitability without risks would be $11.78 \%$.

The indexes of $t$-statistics for factor characteristics (35.19 and 24.35) are much more higher than critical (12.7), it proves statistical importance of the results. The coefficient of determination 0.9997 means that functional dependence between the stock profitability and system and idiosyncratic risks of PJSC Adviivka Coke Plant in 2011 is described with this equation for $99.97 \%$.

Similar research with calculated parameters for other companies and periods under review can be concluded. In addition to that, we should admit, that statistical importance and adequacy of results obtained on other objects is not always proved by the meaning of determination coefficient and $t$-statistics.

Summarizing the obtained results, it is impossible to allocate a single trend as for the direction and strength of the relationship between stock returns of companies and indicators of systemic and idiosyncratic risks. From an economic point of view, this can be explained by the development of low stock market in Ukraine at this stage and limited trading volume of equity securities, the establishment of quotations is influenced by subjective non-market factors rather than on the basis of objective calculations of rates of return and risk. The proof of this thesis is that for enterprises, trading volumes in the securities during the study period were higher, and whose shares are included in the calculation of PTFS index, the best indicators of statistical significance of the results of regression analysis were obtained.

Obtained values of premium of rate coefficients for systematic risk $\left(R_{m}\right)$, idiosyncratic risk $\left(R_{i d}\right)$ and the value of $\alpha_{0}$ are the input parameters (dependent variables) for the realization of the next step of methodological approach to assessing the dependence of changes in the market value of share capital of the company as it implements innovative activity - the conduction of economic-mathematical modeling using multilevel structural equations. These variables are the corresponding indicators of $S R, I R$ and $A R$.

Considering the obtaining of statistically unconfirmed results as for some regression equations received at the previous stage of the research, authors will form two arrays of input data for the structural analysis: total array (36 observations) with the inclusion of input data for all companies and periods, and the limited one (31 observations) - with the exception of statistically unconfirmed settings.

The main exogenous variable with respect to the characteristics of stock returns of the company is innovation activity (IA) of enterprises, because the amount of expenditure on innovation in financial statements of Ukrainian enterprises is not indicated separately, authors will conduct an assessment of their innovation activity by indirect method, defining it through the increase of intangible assets and cost of capital investments of the company during the reporting period. The validity of the use of these indicators for the Ukrainian enterprises connected with the fact that their innovation activities mainly focused on the adaptation of existing innovation through the acquisition of patents and know-how (intangible assets), as well as the development and introduction of new technologies, production upgrading (capital investment).

The level of innovation activity of the enterprise is defined as the ratio of intangible assets increase and capital investments increase to total assets and capital investments to total assets according to the annual financial statements (Table A7 in Appendix). The results of calculation of innovation activity indicators for the studied enterprises for 2011-2013 are presented in Table 5. 
According to the data of Table 5, authors can conclude the level of innovational activity on the explored enterprises of Ukrainian chemical and machine industries is totally low. Along with this, except PJSC Kryukovsky Railway Car Building Works, the dynamics, concerning changing of innovational activity index of observed enterprises, is absent. The presence of negative meanings of innovative activity index affirms the reduction during the period under review of cost of non-material assets and capital investments of the enterprise that negatively characterises the dynamics of its innovative and general development.

Table 5. The level of the innovation activity (IA) of the Ukrainian enterprises in 2011-2013, \%

\begin{tabular}{|l|c|c|c|}
\hline \multirow{2}{*}{ The enterprise } & \multicolumn{2}{c|}{ Years } \\
\cline { 2 - 4 } & 2011 & 2012 & 2013 \\
\hline PJSC Avdiivka Coke Plant & 2.03 & -2.49 & 0.78 \\
\hline PJSC Concern Stirol & 9.54 & -4.02 & 0.62 \\
\hline PJSC Stakhanov Carbon Black Plant & 0.26 & -0.10 & 3.14 \\
\hline PJSC Jasynivsky Chemical-Recovery Plant & -2.68 & -2.15 & -1.37 \\
\hline PJSC Dniprovsky Machine-Bilding Plant & 0.08 & -0.23 & 0.59 \\
\hline PJSC Dniprovagonmash & 0.16 & 0.11 & 0.24 \\
\hline PJSC Ukrainian's Granitic Industry & 0.00 & 0.00 & 0.00 \\
\hline PJSC Khartsyzsk Pipe Plant & -0.53 & -0.10 & 0.08 \\
\hline PJSC Kryukovsky Railway Car Building Works & 0.37 & 0.43 & 0.54 \\
\hline PJSC Luganskteplovoz & -1.29 & 0.71 & 0.32 \\
\hline PJSC Pantec & 0.00 & 0.00 & 0.03 \\
\hline PJSC Stakhanovsky Railway Car Building Works & 0.87 & 1.19 & -1.17 \\
\hline
\end{tabular}

Source: elaborated by the authors from the data of Tables A.7 in Appendix.

According to proposed scientific-methodological approach to the assessment of innovative influence on indices of profitableness and shares of riskiness on the enterprise, the use of two additional parameters acting on the national level and affecting the innovative activity of the enterprise and the level of systematic risk on the level of country innovativeness and the index of economic development are provided in the model. The meanings of these indices for 2011-2013 period are shown in Table 6.

Table 6. The values of the additional parameters of the model

\begin{tabular}{|c|c|c|}
\hline Period & Index of the economical development (IEF) & Level of country innovativeness (GCI) \\
\hline 2011 & 45.8 & 3.29131 \\
\hline 2012 & 46.1 & 3.42601 \\
\hline 2013 & 46.3 & 3.35685 \\
\hline
\end{tabular}

Source: The Heritage Foundation, 2010-2014 and World Economic Forum, 2010-2014.

Both additional parameters, which are observed in the model during 2011-2013 have comparatively stable values. An economic growth index, which according to scale from 0 to 100, presents a general characteristics by 10 economic freedom indices, that affirms the fact that Ukraine in general, is characterized by the average level of economic growth. Index value of country innovativeness is evaluated according to the scale from 1 to 10 and affirms a low level of innovations implementation and technological level of Ukrainian enterprises up to 2011-2013.

Key parameters in the model are return on assets indices (ROA), the number of employees, net sales and the enterprise assets; their values are given at Table A.7 and the Table A.8 in Appendix. Annual financial reporting is an informational basis for the formation of input data unit according to the indicated parameters (Stock Market Infrastructure Development Agency of Ukraine, 2014).

In order to evaluate the parameters of structural equations in software complex Stata 12 we build route diagram, which reflects the choice of endogenous, exogenous and latent variables, as well as their relationship of cause and effect (Figure 1). 


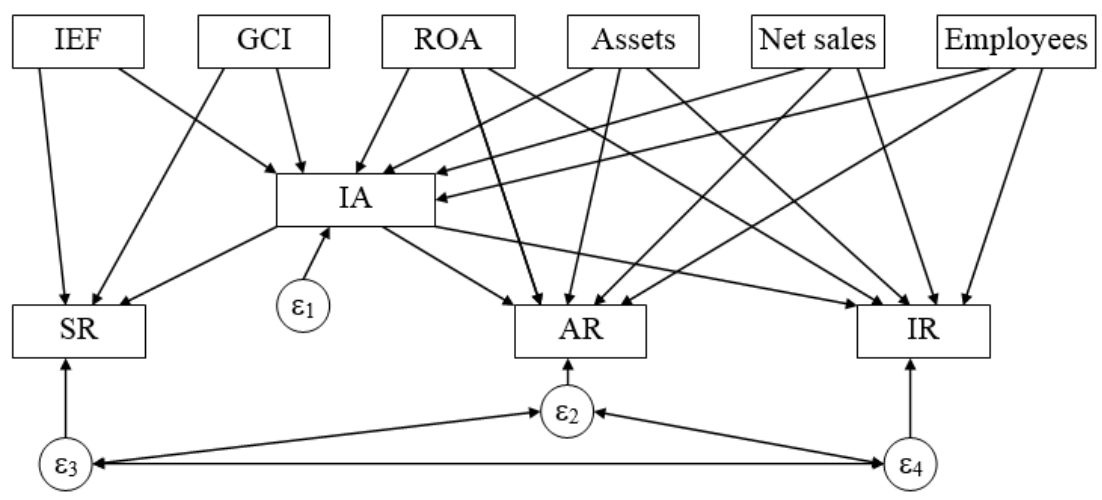

Figure 1. The diagram of the structural equation modeling implementation in the program complex Stata 12

Source: elaborated by the authors using StataCorp, 2013.

The basis of this diagram, i.e. structural model, is formed by interdependence of innovative activity level and excessive profitableness assets, as well as system and idiosyncratic risks, which by-turn depend on nationwide level parameters (additional parameters of model) and on specific ones for the enterprise (key variables). As it was admitted, formalization of cause-and-effect relation between studied parameters is conducted for two samples: general (results of modeling for given array of output values are showered in Figure A.1 in Appendix) and limited sample that does not include statistically insignificant values of Fama-French equations (Figure A.2 in Appendix).

Having analyzed the results of formalization of relation between innovation activities of an enterprise and profitability ratios and indicators of risk of its shares according to both built models one can admit obtaining on the whole similar results. Thus it can be admitted that obtained low values of z-tests for values used in the model in both cases are connected with small number of observations.

Thus, the main conclusions of structural modeling of innovation influence of characteristics of profit and risk while assessing the market value of securities of Ukrainian enterprises are the following:

$>$ It has the greatest impact on the extra profitability (value coefficients in general and limited model are 84.15 and -77.16) among indicators of extra profitability, systematic and idiosyncratic risks of innovation activities of enterprises. Thus, the presence of reverse impact in direction is characterized, that is the increase of innovation expenditures of an enterprise causes the decrease of extra profitability ratios. Such result confirms conclusions of theoretical study that in the countries with a low level of innovation and development of stock market, the innovations are seen as a negative influence on an increase in value (price appreciation, increment of value).

$>$ Both models showed reasonably powerful opposite influence of innovations on the level of systemic risk (-9.08 and -11.60$)$, i.e. The increase of innovative activity of the enterprises, leads to reduction of premium for systemic risk.

$>$ The reserve influence on the systemic risk also demonstrates the additional (optional) parameter of the model - the index of economic freedom, the corresponding coefficients were -2.50 and 1.19. Concerning other additional (optional) parameter, - the level of innovation of a country, it should be noted, that it showed contradicting result. Especially, the formalization of the model uncovers the back-coupling between this indicator and innovative activity of the enterprise. The received result can be explained by the fact that despite improvement of the indicators considering in an innovation index of the country (existence of research institutes, cooperation in the field of researches and technological developments between universities and industry, improvement of protection of intellectual property) during the studied period the volume (amount) of innovative activity for groups of analyzed enterprises has an opposite dynamics;

$>$ Among such control variables as assets volume, net profit, return on assets and labor content, return on assets turned out to be the only measure that can noticeably influence the indexes of the extraordinary income and idiosyncratic risk (the influence of specific industrial factors on the systematic risk was not viewed in this model). Both models proved the evidence of strong direct link between return on assets and extraordinary income (the indexes - 26.15 and 28.24, respectively) and relatively return on assets - idiosyncratic risk feedback (-0.92 and -0.69 , respectively). Economically, such interconnection is quite objective. 
The next step in its formalization is the check of the structural model analysis of interrelation between extraordinary income of systematic and idiosyncratic risks depending on enterprises' innovation activity. Now let's consider the measures, used in software system Stata 12 with this purpose. Let's compare these two models in question.

Table 7. The check of models' adequacy according to key criteria in Stata 12

\begin{tabular}{|c|c|c|}
\hline \multirow{2}{*}{ The adequacy check criterion } & \multicolumn{2}{|c|}{ Index value } \\
\hline & General model & Limited model \\
\hline Likelihood ratio: & $\begin{array}{c}12.771 \\
0.620 \\
40.109 \\
0.103\end{array}$ & $\begin{array}{c}15.569 \\
0.411 \\
49.894 \\
0.013\end{array}$ \\
\hline $\begin{array}{r}\text { Population error: } \\
\text { RMSEA } \\
90 \% \text { week confidence band } \\
\text { Lower boundary } \\
\text { Higher boundary } \\
\text { pclose }\end{array}$ & $\begin{array}{l}0.000 \\
\\
0.000 \\
0.135 \\
0.701\end{array}$ & $\begin{array}{l}0.035 \\
\\
0.000 \\
0.175 \\
0.492 \\
\end{array}$ \\
\hline Information criteria: & $\begin{array}{l}3065.268 \\
3101.689 \\
\end{array}$ & $\begin{array}{l}2633.467 \\
2666.449 \\
\end{array}$ \\
\hline Baseline comparison: & $\begin{array}{l}1.000 \\
1.441 \\
\end{array}$ & $\begin{array}{l}0.971 \\
0.943 \\
\end{array}$ \\
\hline Size of residuals: & $\begin{array}{l}0.079 \\
0.441\end{array}$ & $\begin{array}{l}0.101 \\
0.534\end{array}$ \\
\hline Eigenvalue stability condition & 0 & 0 \\
\hline
\end{tabular}

Source: elaborated by the authors using the data of Figures A.1, A.2 in Appendix.

The likelihood ratio test includes the comparison of developed model and basic model with saturated one. Saturated model perfectly describes the structure of covariation matrix. Index $p>c h i 2$ is analyzed by comparison of saturated and developed models. The closer it to zero, the more we are likely to say, that the developed model describes the structure of covariation matrix of the basic data, as well as the saturated model does (StataCorp, 2013).

The second part of the test involves the comparision of the same criteria of basic and saturated models. The basic model includes a medium and variance of observed variables and covariance of all observed exogenous variables. In the case of two models under review, it can be concluded that constructed models poorly describe the structure of the covariance matrix of the original data, basic - well enough.

The next criterion, RMSEA, means that a square mean value of approximative error is analyzed in conjunction with the definition of the limits of confidence interval. To ensure high quality of models, RMSEA index should be less than 0.05 . Most researchers believe that the model is adequate and well describes the covariance of variables if the lower limit of the $90 \%$ confidence interval is less than 0.05 , and poorly describes the covariance matrix, if the upper limit is more than 0.10 . By this criterion of adequacy, the overall model best describes the relationship between innovations and indicators of yield and securities risk.

AIC and BIC criteria are not used for the adequacy analysis of the constructed models for their absolute value, but they are the basis for comparison of alternative models. The best is less importance of these indicators.

The next group of adequacy criteria includes two indexes - CFI (comparative fit index) and TLI (TuckerLewis index or nonnormed fit index). For both these indexes, the value that indicates the quality and adequacy of the constructed model is a maximum approximation to one. As you can see from the calculation of indexes, both constructed models (general and limited) meet the requirements of these criteria for adequacy.

An important aspect of the analysis in assessing the quality of constructed model variables subject to compliance with the normal distribution law is the assessment of SRMR values (normalized squaremean residual) and CD (coefficient of determination). The SRMR value equals to zero and describes a model that perfectly reflects the covariance of variables. SRMR's low rate does not exceed 0.08, according to most researchers, allowing the 
characterization of a model that describes the structural interrelationships. The coefficient of determination is an analogue of $R^{2}$ to the whole model, where the best value as near as possible to one (StataCorp, 2013).

Assessing constructed models according to SRMR, authors can conclude that the general model satisfies the condition of adequacy and the limited one - imperfectly reflects structural interrelationships. According to the value of determination coefficient of interrelationships between the studied variables, they are described by the first model on $44.1 \%$ and on $53.4 \%$ by the second model.

The stability analysis of the model which determines the possibility of its application by changing the scale of measuring the initial data is one of the most important aspects of designed models researching along with the foregoing characteristics. The model will be stable, if the stability index is less than one. For both constructed models a mentioned index is zero and thus both models are consistent with the condition of stability.

\section{Conclusions}

In such a way, innovations are the one of basic non-financial indexes in competitive position forming of enterprise at the stock market while it use of financial resources. However, the direction of influence of innovative activity on yield, system and idiosyncratic risks, peculiar to securities, is ambiguous and depends on legal, economical (external and internal) and socio-cultural peculiarities of the environment in which innovative enterprises function.

The main criterion in security holdings formation is the provision of risk and income correlation. In terms of investigation in question, it was determined that innovations can influence both expected return on equity and on the level of systematic and idiosyncratic risks. However, the character of its influence is ambiguous and can become apparent not only in a positive way but in a negative one too.

The use of proposed scientific and methodological approach allows to analyze the competitive position of the company on the stock market through the evaluation of overtime profitability of its shares, systematic and idiosyncratic risks, the formation of which is considered in conjunction with the innovative activity of the enterprise and taking into the account investors' attitude to innovations in a particular country, depending on the state level factors (it is expressed by indices of economic development and innovations in the country).

According to the practical approval of scientific and methodological approach to the innovation influence on the earnings yield and risk of enterprise shares on the example of Ukrainian chemical and engineering industries, it was proved that innovation activity of enterprises has a great feedback effect on the above target data of return on equity. This activity also has an essential feedback effect on the systemic risk, in other words, enterprises increase innovation expenses and it leads to cutting of the above target return data and the premiums for systemic risk. Such a result confirms the conclusions of theoretical study that says that innovations are perceived as a negative impact factor on value growth in the countries with a low level of innovations, economic freedom and insufficiently developed stock market. At the same time, innovative activity of the enterprise advances the decrease of stock price exposure of the company from stock market volatility.

Based on the complex statistical analysis of the constructed models, it can be concluded that both models allow reaching statistically significant results and are appropriate that is confirmed by most criteria of model verification of this type. Thus, various tests have shown the advantages of both models are built on the basis of general and limited samples and similarity of results allows to use any of them in analyzing the influence of innovation on overtime profitableness, systematic and idiosyncratic risks of the enterprise.

\section{References}

1. Black, F., Sholes, M. (1974). The Pricing of Options and Corporate Liabilities. Journal of Political Economy, 81(3), 637-654.

2. Bowman D., Gatignon H. (2009). Market response and marketing mix models: trends and research opportunities. Foundations and Trends in Marketing, 3, 129-207.

3. Carhart, M.M. (1997). On Persistence in Mutual Fund Performance. The Journal of Finance, 52(1), 57-82. Retrieved from http://onlinelibrary.wiley.com/enhanced/doi/10.1111/j.1540-6261.1997.tb03808.x/.

4. Chan, L.K.C., Lakonishok, J., Sougiannis, T. (2001). The stock market valuation of research and development expenditures. Journal of Finance, 56(6), 2431-2457.

5. Economic Research. 3-Month Treasury Bill: Secondary Market Rate (2011-2013). Federal Reserve bank of St. Louis. Retrieved from http://research.stlouisfed.org/fred2/series/TB3MS. 
6. Fama, E.F., French, K.R. (1996). Multifactor Explanations of Asset Pricing Anomalies. Journal of Finance, 51, 55-84.

7. Hall, B.H., Oriani, R. (2006). Does the market value R\&D investment by European firms? Evidence from a panel of manufacturing firms in France, Germany, and Italy. International Journal of Industrial Organization, 24(5), 971-993.

8. Hubbard R. Glenn (2004). Money, the Financial System, and the Economy. In M. Savluk, D. Olesnevych (Eds.). Kyiv: KNEU.

9. Kaminskiy, A.B. (2007). Economic-mathematical modelling of the financial risks. Extended abstract of Doctor's thesis. Kyiv (in Ukrainian).

10. Kothari, S., Laguerre, T., Leone, A. (2002). Capitalization versus expensing: evidence on the uncertainty of future earnings from capital expenditures versus R\&D outlays. Review of Accounting Studies, 7, 355-382.

11. Lantz, J.-S., Sahut, J.-M. (2005). R\&D investment and the financial performance of technological firms. International Journal of Business, 10(3), 251-270.

12. Lintner, J. (1965). The Valuation of Risky Assets and the Selection of Risky Investments in Stock Portfolio and Capital Budgets. Review of Economics and Statistics, 13-27.

13. McAlister, L., Srinivasan, R., Kim, M. (2007). Advertising, research and development, and systematic risk of the firm. Journal of Marketing, 71, 35-48.

14. Mossin, J. (1966). Equilibrium in a Capital Asset Market. Econometrica, 34(4), 768-783.

15. Ngobo, P.V., Gatignon, H. (2012). Explaining cross-country differences in the effects of R\&D expenditures on risk and stock returns. INSEAD, p. 50. Retrieved from http://www.insead.edu/facultyresearch/research/doc.cfm?did=50382.

16. Ross, S.A. (1977). Return, Risk and Arbitrage. In Friend, I., Bicksler, J.L. (Eds.). Risk and Return in Finance, 1, pp. 189-218.

17. Sharpe, W.F. (1964). Capital Asset Prices: A Theory of Market Equilibrium under Conditions of Risk. The Journal of Finance, 19(3), pp. 425-442. Retrieved from http://onlinelibrary.wiley.com/doi/10.1111/j.1540-6261.1964.tb02865.x/full.

18. Sharpe, W.F. (1970). Portfolio Theory and Capital Markets. New Jork.

19. StataCorp (2013). Stata structural equatin modeling: reference manual. Release 13. Statistical Software. College Station. Texas: StataCorp LP. Retrieved from http://www.stata.com/manuals13/sem.pdf.

20. Stock Exchange "PFTS". (2010-2013). Retrieved from http://www.pfts.ua/uk/.

21. Stock market infrastructure development agency of Ukraine (2014). Data basis. Retrieved from http://smida.gov.ua/db/emitent/search.

22. The Heritage Foundation (2014). Index of economic freedom: promoting economic opportunity and prosperity by country. Retrieved from http://www.heritage.org/index/.

23. Tobin, J. (1965). The Theory of Portfolio Selection. In Hahn, F.H. and Brechling, F.R.P. (Eds.). The Theory of Interest Rate (pp. 3-51). London: Macmillan.

24. Vitlinskiy, V.V., Velykoivanenko, H.I. (2004). Riskology in the economy and enterprising. Kyiv: KNEU.

25. World Economic Forum. (2014). The Global Competitiveness Report 2014-2015. Retrieved from http://www.weforum.org/reports/global-competitiveness-report-2014-2015. 


\section{Appendices}

Table A.1. Market rate of the Ukrainian enterprises stocks, established by the National Securities and Stock Market Commission (for the last day of the accounting period when the trades were hold)

\begin{tabular}{|c|c|c|c|c|c|c|c|c|c|c|c|c|c|c|}
\hline \multirow[b]{2}{*}{ Enterprise } & \multirow[b]{2}{*}{ Ticker } & \multicolumn{13}{|c|}{ Period } \\
\hline & & $\begin{array}{l}4 \text { qua. } \\
2010\end{array}$ & $\begin{array}{c}1 \text { qua. } \\
2011\end{array}$ & $\begin{array}{l}2 \text { qua. } \\
2011\end{array}$ & $\begin{array}{l}3 \text { qua. } \\
2011\end{array}$ & $\begin{array}{c}4 \text { qua. } \\
2011\end{array}$ & $\begin{array}{l}1 \text { qua. } \\
2012\end{array}$ & $\begin{array}{l}2 \text { qua. } \\
2012\end{array}$ & $\begin{array}{l}3 \text { qua. } \\
2012\end{array}$ & $\begin{array}{l}4 \text { qua. } \\
2012\end{array}$ & $\begin{array}{l}1 \text { qua. } \\
2013\end{array}$ & $\begin{array}{l}2 \text { qua. } \\
2013\end{array}$ & $\begin{array}{l}3 \text { qua. } \\
2013\end{array}$ & $\begin{array}{l}4 \text { qua. } \\
2013\end{array}$ \\
\hline PJSC Avdiivka Coke Plant & AVDK & 14.99 & 14.48 & 11.86 & 6.39 & 6.15 & 5.24 & 2.80 & 3.60 & 3.31 & 3.04 & 3.26 & 3.20 & 3.00 \\
\hline PJSC Concern Stirol & STIR & 86.05 & 79.88 & 55.26 & 30.57 & 36.50 & 25.92 & 15.83 & 17.08 & 13.23 & 11.96 & 12.10 & 10.69 & 12.98 \\
\hline $\begin{array}{l}\text { PJSC Stakhanov Carbon Black } \\
\text { Plant }\end{array}$ & SZTV & 0.50 & 0.39 & 0.51 & 0.50 & 0.70 & 0.75 & 0.73 & 0.65 & 0.66 & 0.66 & 0.66 & 0.66 & 0.66 \\
\hline $\begin{array}{l}\text { PJSC Jasynivsky Chemical- } \\
\text { Recovery Plant }\end{array}$ & YASK & 4.58 & 4.58 & 3.25 & 1.01 & 1.37 & 1.21 & 0.89 & 0.88 & 0.68 & 0.61 & 0.58 & 0.58 & 0.52 \\
\hline $\begin{array}{l}\text { PJSC Dniprovsky Machine- } \\
\text { Bilding Plant }\end{array}$ & DNMZ & 2.10 & 2.10 & 2.10 & 2.10 & 0.18 & 0.18 & 0.16 & 0.07 & 0.13 & 0.57 & 0.70 & 0.60 & 0.60 \\
\hline PJSCDniprovagonmash & DNVM & 53.03 & 70.50 & 65.03 & 66.57 & 70.00 & 69.93 & 80.00 & 80.00 & 80.00 & 80.00 & 80.00 & 157.0 & 157.0 \\
\hline $\begin{array}{l}\text { PJSC Ukrainian's Granitic } \\
\text { Industry }\end{array}$ & GRIU & 3.00 & 3.00 & 3.00 & 3.00 & 3.00 & 3.00 & 3.00 & 3.00 & 3.00 & 3.00 & 3.00 & 3.00 & 3.00 \\
\hline PJSC Khartsyzsk Pipe Plant & HRTR & 1.20 & 1.21 & 1.21 & 0.97 & 0.93 & 1.31 & 0.84 & 0.68 & 0.68 & 0.71 & 0.71 & 0.63 & 0.55 \\
\hline $\begin{array}{l}\text { PJSC Kryukovsky Railway Car } \\
\text { Building Works }\end{array}$ & KVBZ & 35.65 & 34.33 & 23.81 & 17.21 & 22.60 & 21.97 & 17.41 & 18.57 & 19.43 & 21.80 & 23.13 & 19.35 & 17.48 \\
\hline PJSC Luganskteplovoz & LTPL & 4.02 & 4.01 & 2.89 & 2.74 & 2.17 & 2.26 & 2.02 & 1.57 & 1.47 & 1.75 & 1.55 & 1.57 & 1.49 \\
\hline PJSC Pantec & PANK & 1.50 & 1.50 & 1.55 & 1.65 & 2.00 & 2.00 & 2.00 & 2.00 & 2.00 & 2.00 & 2.00 & 2.05 & 2.00 \\
\hline $\begin{array}{l}\text { PJSC Stakhanovsky Railway Car } \\
\text { Building Works }\end{array}$ & SVGZ & 9.43 & 9.43 & 7.53 & 4.45 & 2.88 & 4.46 & 2.65 & 2.62 & 1.70 & 1.58 & 1.31 & 1.29 & 1.29 \\
\hline
\end{tabular}

Source: elaborated by the authors using the data of Stock Exchange "PFTS", 2010-2013. 
Table A.2. Current profitability of the stocks of Ukrainian enterprises, $\%$

\begin{tabular}{|c|c|c|c|c|c|c|c|c|c|c|c|c|c|}
\hline \multirow[b]{2}{*}{ Enterprise } & \multirow[b]{2}{*}{ Ticker } & \multicolumn{12}{|c|}{ Period } \\
\hline & & $\begin{array}{l}1 \text { qua. } \\
2011\end{array}$ & $\begin{array}{l}2 \text { qua. } \\
2011\end{array}$ & $\begin{array}{l}3 \text { qua. } \\
2011\end{array}$ & $\begin{array}{l}4 \text { qua. } \\
2011\end{array}$ & $\begin{array}{l}1 \text { qua. } \\
2012\end{array}$ & $\begin{array}{l}2 \text { qua. } \\
2012\end{array}$ & $\begin{array}{l}3 \text { qua. } \\
2012\end{array}$ & $\begin{array}{l}4 \text { qua. } \\
2012\end{array}$ & $\begin{array}{l}1 \text { qua. } \\
2013\end{array}$ & $\begin{array}{l}2 \text { qua. } \\
2013\end{array}$ & $\begin{array}{l}3 \text { qua. } \\
2013\end{array}$ & $\begin{array}{l}4 \text { qua. } \\
2013\end{array}$ \\
\hline PJSC Avdiivka Coke Plant & AVDK & -3.41 & -18.09 & -46.13 & -3.69 & -14.86 & -46.56 & 28.40 & -8.06 & -8.06 & 7.29 & -1.71 & -6.55 \\
\hline PJSC Concern Stirol & STIR & -7.18 & -30.82 & -44.69 & 19.42 & -28.97 & -38.92 & 7.88 & -22.56 & -9.60 & 1.17 & -11.69 & 21.43 \\
\hline PJSC Stakhanov Carbon Black Plant & SZTV & -22.64 & 31.77 & -1.90 & 40.00 & 7.14 & -2.67 & -10.96 & 1.58 & 0.03 & -0.08 & 0.00 & 0.08 \\
\hline PJSC Jasynivsky Chemical-Recovery Plant & YASK & -0.22 & -28.91 & -68.95 & 35.64 & -11.36 & -26.65 & -1.58 & -22.72 & -10.32 & -5.35 & 0.09 & -9.12 \\
\hline PJSC Dniprovsky Machine-Bilding Plant & DNMZ & 0.00 & 0.00 & 0.00 & -91.43 & 0.00 & -11.11 & -58.13 & 96.12 & 330.29 & 23.81 & -14.29 & 0.00 \\
\hline PJSC Dniprovagonmash & DNVM & 32.95 & -7.75 & 2.36 & 5.15 & -0.10 & 14.40 & 0.00 & 0.00 & 0.00 & 0.00 & 96.25 & 0.00 \\
\hline PJSC Ukrainian's Granitic Industry & GRIU & -0.03 & 0.00 & 0.00 & 0.00 & 0.00 & 0.00 & 0.00 & 0.00 & 0.00 & 0.00 & 0.00 & 0.00 \\
\hline PJSC Khartsyzsk Pipe Plant & HRTR & 0.61 & 0.22 & -19.53 & -4.12 & 40.64 & -36.29 & -19.09 & 1.15 & 3.91 & 0.14 & -11.54 & -13.11 \\
\hline $\begin{array}{l}\text { PJSC Kryukovsky Railway Car Building } \\
\text { Works }\end{array}$ & KVBZ & -3.72 & -30.65 & -27.70 & 31.32 & -2.77 & -20.76 & 6.66 & 4.60 & 12.23 & 6.08 & -16.34 & -9.67 \\
\hline PJSC Luganskteplovoz & LTPL & $\begin{array}{l}-0.32 \\
\end{array}$ & -28.05 & -5.03 & -20.99 & 4.16 & -10.21 & -22.68 & -6.07 & 18.77 & -11.08 & 1.22 & -5.53 \\
\hline PJSC Pantec & PANK & 0.00 & 3.59 & 6.19 & 21.21 & 0.00 & 0.00 & 0.00 & 0.03 & -0.02 & 0.00 & 2.30 & -2.24 \\
\hline $\begin{array}{l}\text { PJSC Stakhanovsky Railway Car } \\
\text { Building Works }\end{array}$ & SVGZ & 0.00 & -20.21 & -40.93 & -35.21 & 54.92 & -40.61 & -1.32 & -34.86 & -7.37 & -16.97 & -1.56 & -0.01 \\
\hline
\end{tabular}

Source: elaborated by the authors from the data of Stock Exchange "PFTS", 2010-2013. 
Table A.3. Input data for the calculation of the market capitalization and interrelation of the book and market prices

\begin{tabular}{|c|c|c|c|c|c|c|c|c|c|c|c|c|c|c|}
\hline \multirow[b]{2}{*}{ Enterprise } & \multirow[b]{2}{*}{ Ticker } & \multirow{2}{*}{$\begin{array}{l}\text { Quantity of } \\
\text { stocks }\end{array}$} & \multicolumn{12}{|c|}{ Equity, thousands UAH. } \\
\hline & & & $\begin{array}{l}4 \text { qua. } \\
2010\end{array}$ & $\begin{array}{l}1 \text { qua. } \\
2011\end{array}$ & $\begin{array}{l}2 \text { qua. } \\
2011\end{array}$ & $\begin{array}{l}3 \text { qua. } \\
2011\end{array}$ & $\begin{array}{l}4 \text { qua. } \\
2011\end{array}$ & $\begin{array}{l}1 \text { qua. } \\
2012\end{array}$ & $\begin{array}{l}2 \text { qua. } \\
2012\end{array}$ & $\begin{array}{l}3 \text { qua. } \\
2012\end{array}$ & $\begin{array}{l}4 \text { qua. } \\
2012\end{array}$ & $\begin{array}{l}1 \text { qua. } \\
2013\end{array}$ & $\begin{array}{l}2 \text { qua. } \\
2013\end{array}$ & $\begin{array}{l}3 \text { qua. } \\
2013\end{array}$ \\
\hline PJSC Avdiivka Coke Plant & AVDK & 195062500 & 6004923 & 5990568 & 5877033 & 5763497 & 5786909 & 5568895 & 5350881 & 5132867 & 5089679 & 5128042 & 5108214 & 4855213 \\
\hline PJSC Concern Stirol & STIR & 27125280 & 1633081 & 1520452 & 1497986 & 1418540 & 1283408 & 516273 & 16300 & -406028 & -961441 & -1532852 & -1513447 & -1879269 \\
\hline $\begin{array}{l}\text { PJSC Stakhanov Carbon } \\
\text { Black Plant }\end{array}$ & SZTV & 800873978 & 185923 & 186625 & 174617 & 175984 & 139210 & 121247 & 141945 & 114432 & 202979 & 173248 & 143517 & 113786 \\
\hline $\begin{array}{l}\text { PJSC Jasynivsky Chemical- } \\
\text { Recovery Plant }\end{array}$ & YASK & 273598680 & 939334 & 941537 & 1051671 & 1164008 & 1273041 & 1340884 & 1429872 & 1518861 & 1560741 & 1540618 & 1520495 & 1500372 \\
\hline $\begin{array}{l}\text { PJSC Dniprovsky Machine- } \\
\text { Bilding Plant }\end{array}$ & DNMZ & 142609000 & 100631 & 105640 & 112884 & 113601 & 75854 & 80519 & 74596 & 61420 & 56306 & 56450 & 57890 & 58783 \\
\hline PJSC Dniprovagonmash & DNVM & 16635800 & 451904 & 701772 & 647581 & 834291 & $500+00$ & 1183541 & 1158098 & 1353407 & 1451569 & 1450844 & 1523478 & 1540006 \\
\hline $\begin{array}{l}\text { PJSC Ukrainian's Granitic } \\
\text { Industry }\end{array}$ & GRIU & 119200000 & 234587 & 234599 & 234600 & 234601 & 234860 & 234861 & 235521 & 235522 & 237885 & 238216 & 239123 & 240030 \\
\hline PJSC Khartsyzsk Pipe Plant & HRTR & 2598495120 & 1357344 & 1375088 & 671380 & 1004704 & 1263427 & 1459536 & 1239510 & 1254061 & 1177049 & 1189623 & 1229778 & 1235343 \\
\hline $\begin{array}{l}\text { PJSC Kryukovsky Railway } \\
\text { Car Building Works }\end{array}$ & KVBZ & 112287457 & 1501126 & 1756787 & 1905471 & 2011347 & 2181435 & 2355787 & 2517304 & 2678822 & 2828187 & 2809364 & 2807692 & 2786412 \\
\hline PJSC Luganskteplovoz & LTPL & 219184684 & -23969 & -45869 & 102056 & 432140 & 575371 & 575462 & 575553 & 584799 & 614095 & 652819 & 691543 & 730267 \\
\hline PJSC Pantec & PANK & 36000000 & 21591 & 21601 & 21611 & 21615 & 21621 & 21651 & 21601 & 21580 & 21517 & 21517 & 21521 & 21525 \\
\hline $\begin{array}{l}\text { PJSC Stakhanovsky Rail- } \\
\text { way Car Building Works }\end{array}$ & SVGZ & 226389510 & 646264 & 705831 & 767074 & 771741 & 749017 & 761333 & 783375 & 732235 & 753752 & 754498 & 755420 & 756301 \\
\hline
\end{tabular}

Source: elaborated by the authors from the data of Stock Exchange "PFTS", 2010-2013 and Stock Market Infrastructure Development Agency of Ukraine, $2010-2013$. 
Table A.4. Markers of the market capitalization of the Ukrainian enterprises, thousands UAH

\begin{tabular}{|c|c|c|c|c|c|c|c|c|c|c|c|c|c|}
\hline \multirow[b]{2}{*}{ Enterprise } & \multirow[b]{2}{*}{ Ticker } & \multicolumn{12}{|c|}{ Period } \\
\hline & & $\begin{array}{l}4 \text { qua. } \\
2010\end{array}$ & $\begin{array}{l}1 \text { qua. } \\
2011\end{array}$ & $\begin{array}{l}2 \text { qua. } \\
2011\end{array}$ & $\begin{array}{l}3 \text { qua. } \\
2011\end{array}$ & $\begin{array}{l}4 \text { qua. } \\
2011\end{array}$ & $\begin{array}{l}1 \text { qua. } \\
2012\end{array}$ & $\begin{array}{l}2 \text { qua. } \\
2012\end{array}$ & $\begin{array}{l}3 \text { qua. } \\
2012\end{array}$ & $\begin{array}{l}4 \text { qua. } \\
2012\end{array}$ & $\begin{array}{l}1 \text { qua. } \\
2013\end{array}$ & $\begin{array}{l}2 \text { qua. } \\
2013\end{array}$ & $\begin{array}{l}3 \text { qua. } \\
2013\end{array}$ \\
\hline PJSC Avdiivka Coke Plant & AVDK & 2924533 & 2824856 & 2313753 & 1246527 & 1200493 & 1022128 & 546175 & 701289 & 644779 & 592795 & 636001 & 625156 \\
\hline PJSC Concern Stirol & STIR & 2334130 & 2166632 & 1498943 & 829084 & 990073 & 703212 & 429510 & 463373 & 358857 & 324418 & 328216 & 289834 \\
\hline PJSC Stakhanov Carbon Black Plant & SZTV & 400437 & 309778 & 408205 & 400437 & 560612 & 600655 & 584638 & 520568 & 528817 & 528977 & 528577 & 528577 \\
\hline $\begin{array}{l}\text { PJSC Jasynivsky Chemical-Recovery } \\
\text { Plant }\end{array}$ & YASK & 1254423 & 1251714 & 889880 & 276335 & 374830 & 332231 & 243694 & 239837 & 185336 & 166211 & 157319 & 157456 \\
\hline $\begin{array}{l}\text { PJSC Dniprovsky Machine-Bilding } \\
\text { Plant }\end{array}$ & DNMZ & 299479 & 299479 & 299479 & 299479 & 25670 & 25670 & 22817 & 9555 & 18739 & 80631 & 99826 & 85565 \\
\hline PJSC Dniprovagonmash & DNVM & 882160 & 1172836 & 1081883 & 1107445 & 1164506 & 1163313 & 1330864 & 1330864 & 1330864 & 1330864 & 1330864 & 2611821 \\
\hline PJSC Ukrainian's Granitic Industry & GRIU & 357695 & 357600 & 357600 & 357600 & 357600 & 357600 & 357600 & 357600 & 357600 & 357600 & 357600 & 357600 \\
\hline PJSC Khartsyzsk Pipe Plant & HRTR & 3118194 & 3137163 & 3144179 & 2530155 & 2425955 & 3411824 & 2173641 & 1758661 & 1778930 & 1848569 & 1851168 & 1637572 \\
\hline $\begin{array}{l}\text { PJSC Kryukovsky Railway Car Build- } \\
\text { ing Works }\end{array}$ & KVBZ & 4003351 & 3854267 & 2673003 & 1932467 & 2537697 & 2467360 & 1955037 & 2085178 & 2181184 & 2447867 & 2596647 & 2172302 \\
\hline PJSC Luganskteplovoz & LTPL & 881692 & 878843 & 632348 & 600566 & 474535 & 494261 & 443805 & 343134 & 322311 & 382806 & 340394 & 344558 \\
\hline PJSC Pantec & PANK & 54000 & 54000 & 55937 & 59400 & 72000 & 72000 & 72000 & 72000 & 72018 & 72000 & 72000 & 73652 \\
\hline $\begin{array}{l}\text { PJSC Stakhanovsky Railway Car } \\
\text { Building Works }\end{array}$ & SVGZ & 2135012 & 2135012 & 1703581 & 1006301 & 652002 & 1010082 & 599932 & 592009 & 385609 & 357175 & 296570 & 291929 \\
\hline
\end{tabular}

Notes:

big enterprises according to the level of the market capitalization;

small enterprises according to the level of the market capitalization.

Source: elaborated by the authors from the data of Tables A.1, A.3. 
Table A.5. Markers of the interrelation of the book and market prices of Ukrainian enterprises

\begin{tabular}{|c|c|c|c|c|c|c|c|c|c|c|c|c|c|}
\hline \multirow[b]{2}{*}{ Enterprise } & \multirow[b]{2}{*}{ Ticker } & \multicolumn{12}{|c|}{ Period } \\
\hline & & $\begin{array}{l}4 \text { qua. } \\
2010\end{array}$ & $\begin{array}{l}1 \text { qua. } \\
2011\end{array}$ & $\begin{array}{l}2 \text { qua. } \\
2011 \\
\end{array}$ & $\begin{array}{l}3 \text { qua. } \\
2011\end{array}$ & $\begin{array}{l}4 \text { qua. } \\
2011 \\
\end{array}$ & $\begin{array}{l}1 \text { qua. } \\
2012\end{array}$ & $\begin{array}{l}2 \text { qua. } \\
2012\end{array}$ & $\begin{array}{l}3 \text { qua. } \\
2012 \\
\end{array}$ & $\begin{array}{l}4 \text { qua. } \\
2012\end{array}$ & $\begin{array}{l}1 \text { qua. } \\
2013\end{array}$ & $\begin{array}{l}2 \text { qua. } \\
2013\end{array}$ & $\begin{array}{l}3 \text { qua. } \\
2013\end{array}$ \\
\hline PJSC Avdiivka Coke Plant & AVDK & 2.0533 & 2.1207 & 2.5400 & 4.6236 & 4.8204 & 5.4483 & 9.7970 & 7.3192 & 7.8937 & 8.6506 & 8.0318 & 7.7664 \\
\hline PJSC Concern Stirol & STIR & 0.6997 & 0.7018 & 0.9994 & 1.7110 & 1.2963 & 0.7342 & 0.0380 & -0.8762 & -2.6792 & -4.7249 & -4.6111 & -6.4840 \\
\hline PJSC Stakhanov Carbon Black Plant & SZTV & 0.4643 & 0.6024 & 0.4278 & 0.4395 & 0.2483 & 0.2019 & 0.2428 & 0.2198 & 0.3838 & 0.3275 & 0.2715 & 0.2153 \\
\hline $\begin{array}{l}\text { PJSC Jasynivsky Chemical-Recovery } \\
\text { Plant }\end{array}$ & YASK & 0.7488 & 0.7522 & 1.1818 & 4.2123 & 3.3963 & 4.0360 & 5.8675 & 6.3329 & 8.4212 & 9.2690 & 9.6650 & 9.5288 \\
\hline PJSC Dniprovsky Machine-Bilding Plant & DNMZ & 0.3360 & 0.3527 & 0.3769 & 0.3793 & 2.9550 & 3.1367 & 3.2693 & 6.4282 & 3.0048 & 0.7001 & 0.5799 & 0.6870 \\
\hline PJSC Dniprovagonmash & DNVM & 0.5123 & 0.5984 & 0.5986 & 0.7533 & 0.7990 & 1.0174 & 0.8702 & 1.0169 & 1.0907 & 1.0902 & 1.1447 & 0.5896 \\
\hline PJSC Ukrainian's Granitic Industry & GRIU & 0.6558 & 0.6560 & 0.6560 & 0.6560 & 0.6568 & 0.6568 & 0.6586 & 0.6586 & 0.6652 & 0.6662 & 0.6687 & 0.6712 \\
\hline PJSC Khartsyzsk Pipe Plant & HRTR & 0.4353 & 0.4383 & 0.2135 & 0.3971 & 0.5208 & 0.4278 & 0.5702 & 0.7131 & 0.6617 & 0.6435 & 0.6643 & 0.7544 \\
\hline $\begin{array}{l}\text { PJSC Kryukovsky Railway Car Building } \\
\text { Works }\end{array}$ & KVBZ & 0.3750 & 0.4558 & 0.7129 & 1.0408 & 0.8596 & 0.9548 & 1.2876 & 1.2847 & 1.2966 & 1.1477 & 1.0813 & 1.2827 \\
\hline PJSC Luganskteplovoz & LTPL & -0.0272 & -0.052 & 0.1614 & 0.7196 & 1.2125 & 1.1643 & 1.2969 & 1.7043 & 1.9053 & 1.7054 & 2.0316 & 2.1194 \\
\hline PJSC Pantec & PANK & 0.3998 & 0.4000 & 0.3863 & 0.3639 & 0.3003 & 0.3007 & 0.3000 & 0.2997 & 0.2988 & 0.2988 & 0.2989 & 0.2923 \\
\hline $\begin{array}{l}\text { PJSC Stakhanovsky Railway Car } \\
\text { Building Works }\end{array}$ & SVGZ & 0.3027 & 0.3306 & 0.4503 & 0.7669 & 1.1488 & 0.7537 & 1.3058 & 1.2369 & 1.9547 & 2.1124 & 2.5472 & 2.5907 \\
\hline
\end{tabular}

Notes:

high level of interrelation between book and market prices;

middle level of interrelation between book and market prices;

low level of interrelation between book and market prices.

Source: elaborated by the authors from the data of Tables A.3, A.4. 
Table A.6. Results of the regressive analysis of the Fama-French Model

\begin{tabular}{|c|c|c|c|c|c|c|c|c|c|}
\hline \multirow{2}{*}{ Criteria } & \multicolumn{3}{|c|}{2011} & \multicolumn{3}{|c|}{2012} & \multicolumn{3}{|c|}{2013} \\
\hline & Coficient & Standard deficiency & t-statistics & Coficient & Standard deficiency & t- statistics & Coficient & Standard deficiency & t-statistics \\
\hline \multicolumn{10}{|c|}{ PJSC Avdiivka Coke Plant } \\
\hline$R_{m}$ & 0.6381 & 0.0181 & 35.19 & 2.1763 & 1.0281 & 2.12 & -2.0349 & 0.7859 & -2.59 \\
\hline$R_{i d}$ & 0.2578 & 0.0106 & 24.35 & 0.3814 & 0.4904 & 0.78 & -0.0135 & 0.0335 & -0.40 \\
\hline Cons. & -11.7797 & 0.3811 & -30.91 & 13.6669 & 16.1487 & 0.85 & -6.4757 & 2.9951 & -2.16 \\
\hline$R^{2}$ & 0.9997 & & & 0.8288 & & & 0.9093 & & \\
\hline \multicolumn{10}{|c|}{ PJSC Concern Stirol } \\
\hline$R_{m}$ & 0.5854 & 0.4886 & 1.20 & 1.5721 & 0.7249 & 2.17 & 2.8573 & 1.2931 & 2.21 \\
\hline$R_{i d}$ & 0.4153 & 0.2426 & 1.71 & 0.4606 & 0.2839 & 1.62 & -0.1486 & 0.1007 & -1.48 \\
\hline Cons. & -11.2707 & 9.2181 & -1.22 & -0.6481 & 10.3652 & -0.06 & 11.5975 & 8.4882 & 1.37 \\
\hline$R^{2}$ & 0.7464 & & & 0.7332 & & & 0.7440 & & \\
\hline \multicolumn{10}{|c|}{ PJSC Stakhanov Carbon Black Plant } \\
\hline$R_{m}$ & -1.8131 & 0.1552 & -7.62 & 0.5767 & 0.8607 & 0.67 & 0.0198 & 0.0027 & 7.31 \\
\hline$R_{i d}$ & 0.9297 & 0.0906 & 10.26 & 0.3659 & 0.3371 & 1.09 & -0.0005 & 0.0001 & -4.29 \\
\hline Cons. & -8.2045 & 3.2619 & -2.52 & 10.2371 & 12.3076 & 0.83 & 0.0088 & 0.0103 & 0.86 \\
\hline$R^{2}$ & 0.9911 & & & 0.3872 & & & 0.9820 & & \\
\hline \multicolumn{10}{|c|}{ PJSC Jasynivsky Chemical-Recovery Plant } \\
\hline$R_{m}$ & 0.9294 & 0.8908 & 1.04 & 0.5360 & 0.4145 & 1.29 & -0.8166 & 1.1440 & -0.71 \\
\hline$R_{i d}$ & 0.7588 & 0.5201 & 1.46 & -0.0852 & 0.1977 & -0.43 & -0.0241 & 0.0488 & -0.49 \\
\hline Cons. & -9.1266 & 18.7203 & -0.49 & -10.3550 & 6.5103 & -1.59 & -7.3518 & 4.3612 & -1.69 \\
\hline$R^{2}$ & 0.8719 & & & 0.7961 & & & 0.5804 & & \\
\hline \multicolumn{10}{|c|}{ PJSC Dniprovsky Machine-Bilding Plant } \\
\hline$R_{m}$ & 0.4055 & 1.8688 & 0.22 & 1.1539 & 4.0051 & 0.29 & -2.3593 & 3.7674 & -0.63 \\
\hline$R_{i d}$ & -0.9717 & 1.0911 & -0.89 & 1.5372 & 1.9103 & 0.80 & 2.3719 & 0.1607 & 14.75 \\
\hline Cons. & -12.0591 & 39.2717 & -0.31 & 23.8958 & 62.9093 & 0.38 & 9.7410 & 14.3617 & 0.68 \\
\hline$R^{2}$ & 0.4705 & & & 0.4131 & & & 0.9963 & & \\
\hline \multicolumn{10}{|c|}{ PJSC Dniprovagonmash } \\
\hline$R_{m}$ & 0.9562 & 0.1617 & 5.91 & -0.5327 & 0.1372 & -3.88 & -3.1526 & 16.6214 & -0.19 \\
\hline$R_{i d}$ & -0.3568 & 0.0944 & -3.78 & -0.0773 & 0.6545 & -1.18 & -0.1794 & 0.7092 & -0.25 \\
\hline Cons. & 21.8334 & 3.3985 & 6.42 & -2.3389 & 2.1554 & -1.09 & 22.2269 & 63.3632 & 0.35 \\
\hline$R^{2}$ & 0.9726 & & & 0.9446 & & & 0.1561 & & \\
\hline
\end{tabular}


Table A.6 (cont.). Results of the regressive analysis of the Fama-French Model

\begin{tabular}{|c|c|c|c|c|c|c|c|c|c|}
\hline \multirow{2}{*}{ Criteria } & \multicolumn{3}{|c|}{2011} & \multicolumn{3}{|c|}{2012} & \multicolumn{3}{|c|}{2013} \\
\hline & Coficient & Standard deficiency & t-statistics & Coficient & Standard deficiency & t-statistics & Coficient & Standard deficiency & t-statistics \\
\hline \multicolumn{10}{|c|}{ PJSC Ukrainian's Granitic Industry } \\
\hline$R_{m}$ & -0.0035 & 0.0015 & -2.31 & -0.0002 & 0.0008 & -0.32 & -0.0044 & 0.0019 & -2.32 \\
\hline$R_{i d}$ & 0.0012 & 0.0009 & 1.40 & -0.0003 & 0.0004 & -0.76 & -0.0002 & 0.0001 & -2.67 \\
\hline Cons. & -0.1103 & 0.0322 & -3.42 & -0.0912 & 0.0126 & -7.24 & -0.0610 & 0.0072 & -8.41 \\
\hline$R^{2}$ & 0.8429 & & & 0.3776 & & & 0.9590 & & \\
\hline \multicolumn{10}{|c|}{ PJSC Khartsyzsk Pipe Plant } \\
\hline$R_{m}$ & 0.2384 & 0.2390 & 1.00 & 0.8619 & 1.9539 & 0.44 & -1.8260 & 1.1988 & -1.52 \\
\hline$R_{i d}$ & 0.1268 & 0.1395 & 0.91 & -0.3733 & 0.9320 & -0.40 & 0.1233 & 0.0511 & 2.41 \\
\hline Cons. & -3.6646 & 5.0221 & -0.73 & 4.2518 & 30.6910 & 0.912 & -12.9296 & 4.5699 & -2.83 \\
\hline$R^{2}$ & 0.7969 & & & 0.4667 & & & 0.8574 & & \\
\hline \multicolumn{10}{|c|}{ PJSC Kryukovsky Railway Car Building Works } \\
\hline$R_{m}$ & 0.4331 & 1.1721 & 0.37 & 1.0011 & 0.0007 & 1381.29 & -1.888 & 2.8915 & -0.65 \\
\hline$R_{i d}$ & 0.3660 & 0.6843 & 0.53 & 0.2415 & 0.0003 & 698.71 & 0.1743 & 0.1234 & 1.41 \\
\hline Cons. & -4.7700 & 24.6310 & -0.19 & 8.1207 & 0.0114 & 713.32 & -11.3465 & 11.0226 & -1.03 \\
\hline$R^{2}$ & 0.4712 & & & 1.0000 & & & 0.6661 & & \\
\hline \multicolumn{10}{|c|}{ PJSC Luganskteplovoz } \\
\hline$R_{m}$ & 0.4860 & 0.1977 & 2.46 & -0.2728 & 0.5090 & -0.54 & 0.5539 & 1.9194 & 0.29 \\
\hline$R_{i d}$ & -0.4049 & 0.1154 & -3.51 & -0.1924 & 0.1993 & -0.97 & 0.1564 & 0.0819 & 1.91 \\
\hline Cons. & -5.3096 & 4.1542 & -1.28 & -12.6757 & 7.2779 & -1.74 & -2.5789 & 7.3170 & -0.35 \\
\hline$R^{2}$ & 0.9274 & & & 0.3267 & & & 0.8444 & & \\
\hline \multicolumn{10}{|c|}{ PJSC Pantec } \\
\hline$R_{m}$ & -0.1601 & 0.2430 & -0.66 & 0.3215 & 0.3657 & 0.88 & -0.4530 & 0.5311 & -0.85 \\
\hline$R_{i d}$ & 0.1644 & 0.1206 & 1.36 & 0.2083 & 0.1432 & 1.45 & 0.0081 & 0.0227 & 0.36 \\
\hline Cons. & 5.1832 & 4.5840 & 1.13 & 5.9861 & 5.2287 & 1.14 & -1.2996 & 2.0245 & -0.64 \\
\hline$R^{2}$ & 0.4939 & & & 0.5298 & & & 0.4219 & & \\
\hline \multicolumn{10}{|c|}{ PJSC Stakhanovsky Railway Car Building Works } \\
\hline$R_{m}$ & 0.8440 & 0.5522 & 1.53 & 0.6206 & 1.0003 & 0.62 & 2.9687 & 0.6467 & 4.59 \\
\hline$R_{i d}$ & -0.1751 & 0.3224 & -0.54 & -1.1044 & 0.4771 & -2.31 & -0.0701 & 0.0503 & -1.39 \\
\hline Cons. & -12.8989 & 11.6038 & -1.11 & -2.8161 & 15.7121 & -0.18 & 1.8000 & 4.2451 & 0.42 \\
\hline$R^{2}$ & 0.7096 & & & 0.9202 & & & 0.9136 & & \\
\hline
\end{tabular}

ource: elaborated by the authors from the data of Tables A.1-A.5, and 3-Month Treasury Bill: Secondary Market Rate, 2010-2013. 
Table A.7. Input data for the calculation of the level of the innovation activity of the enterprise

\begin{tabular}{|c|c|c|c|c|c|c|c|c|c|c|c|c|}
\hline \multirow{2}{*}{ Enterprise } & \multicolumn{4}{|c|}{ Assets, thousands UAH. } & \multicolumn{4}{|c|}{ Intangible assets, thousands UAH. } & \multicolumn{4}{|c|}{ Capital investments, thousands UAH. } \\
\hline & 2010 & 2011 & 2012 & 2013 & 2010 & 2011 & 2012 & 2013 & 2010 & 2011 & 2012 & 2013 \\
\hline PJSC Avdiivka Coke Plant & 12898763 & 10982830 & 9436264 & 7881209 & 11558 & 9430 & 9128 & 12837 & 217416 & 462084 & 208533 & 272072 \\
\hline PJSC Concern Stirol & 3235700 & 4720605 & 7570177 & 13081287 & 154329 & 130553 & 106360 & 82900 & 164385 & 567699 & 344664 & 431791 \\
\hline PJSC Stakhanov Carbon Black Plant & 1565131 & 1154209 & 1232151 & 915270 & 80 & 100 & 56 & 22 & 3662 & 7140 & 6035 & 39737 \\
\hline PJSC Jasynivsky Chemical-Recovery Plant & 2024318 & 2864731 & 2070139 & 2269680 & 171 & 301 & 507 & 637 & 281148 & 215511 & 162165 & 132325 \\
\hline PJSC Dniprovsky Machine-Bilding Plant & 155680 & 207721 & 181552 & 182580 & 277 & 65 & 38 & 24 & 163 & 513 & 83 & 1163 \\
\hline PJSC Dniprovagonmash & 974107 & 1614330 & 1889081 & 1667475 & 1106 & 3149 & 5100 & 9367 & 0 & 0 & 0 & 0 \\
\hline PJSC Ukrainian's Granitic Industry & 348915 & 559279 & 752276 & 728386 & 0 & 0 & 0 & 0 & 0 & 0 & 0 & 0 \\
\hline PJSC Khartsyzsk Pipe Plant & 3292226 & 4327127 & 3180509 & 2376888 & 5787 & 4576 & 3756 & 2956 & 27024 & 8018 & 4976 & 8052 \\
\hline PJSC Kryukovsky Railway Car Building Works & 2064322 & 3018043 & 3885111 & 4348745 & 4276 & 28619 & 41732 & 55273 & 47047 & 32020 & 33902 & 42580 \\
\hline PJSC Luganskteplovoz & 668377 & 1308004 & 1612758 & 1923259 & 802 & 1139 & 2757 & 6370 & 16551 & 3424 & 12180 & 14143 \\
\hline PJSC Pantec & 24028 & 23811 & 22497 & 56805 & 0 & 0 & 1 & 11 & 0 & 0 & 0 & 0 \\
\hline $\begin{array}{l}\text { PJSC Stakhanovsky Railway Car } \\
\text { Building Works }\end{array}$ & 2629579 & 2561499 & 1990934 & 1494566 & 7 & 727 & 863 & 758 & 31931 & 53724 & 80738 & 60510 \\
\hline
\end{tabular}

ource: elaborated by the authors from the data of Stock Market Infrastructure Development Agency of Ukraine, 2010-2013.

Table A.8. Test exogenous models for the conduction of the structural analysis

\begin{tabular}{|c|c|c|c|c|c|c|c|c|c|}
\hline \multirow{2}{*}{ Enterprise } & \multicolumn{3}{|c|}{ Profit, thousands UAH. } & \multicolumn{3}{|c|}{ Profitability of the assets, $\%$} & \multicolumn{3}{|c|}{ Quantity of the workers } \\
\hline & 2011 & 2012 & 2013 & 2011 & 2012 & 2013 & 2011 & 2012 & 2013 \\
\hline PJSC Avdiivka Coke Plant & 11637080 & 8830124 & 7334500 & -2.16 & -10.87 & -2.25 & 4254 & 4173 & 3958 \\
\hline PJSC Concern Stirol & 5290037 & 6504115 & 4375699 & -8.79 & -36.53 & -17.09 & 4365 & 4496 & 4330 \\
\hline PJSC Stakhanov Carbon Black Plant & 353985 & 244330 & 237240 & -2.68 & -4.82 & -13.98 & 710 & 712 & 664 \\
\hline PJSC Jasynivsky Chemical-Recovery Plant & 4580637 & 3501122 & 2800064 & 3.50 & 2.90 & -1.05 & 3309 & 3286 & 3331 \\
\hline PJSC Dniprovsky Machine-Bilding Plant & 113171 & 48398 & 55246 & -2.05 & -10.69 & -0.26 & 295 & 217 & 141 \\
\hline PJSC Dniprovagonmash & 4517720 & 3910989 & 1326392 & 62.39 & 46.94 & 9.16 & 3991 & 4111 & 3457 \\
\hline PJSC Ukrainian's Granitic Industry & 565 & 283 & 1 & 0.06 & 0.46 & 0.32 & 3 & 3 & 3 \\
\hline PJSC Khartsyzsk Pipe Plant & 6220069 & 3887647 & 1102905 & 20.68 & 7.32 & 1.38 & 3147 & 2809 & 2580 \\
\hline PJSC Kryukovsky Railway Car Building Works & 6236143 & 7216141 & 3769154 & 25.13 & 22.64 & 8.24 & 8030 & 8450 & 8409 \\
\hline PJSC Luganskteplovoz & 1753979 & 1731475 & 3038535 & 1.56 & 2.65 & 8.95 & 5964 & 5786 & 5920 \\
\hline PJSC Pantec & 1360 & 451 & 420 & 0.13 & -0.45 & 0.02 & 2 & 2 & 2 \\
\hline PJSC Stakhanovsky Railway Car Building Works & 3497113 & 2939547 & 1413906 & 6.15 & 0.21 & 0.25 & 4726 & 4774 & 3910 \\
\hline
\end{tabular}

ource: elaborated by the authors from the data of Stock Market Infrastructure Development Agency of Ukraine, 2010-2013. 


\begin{tabular}{|c|c|c|c|c|c|c|}
\hline \multicolumn{7}{|c|}{ 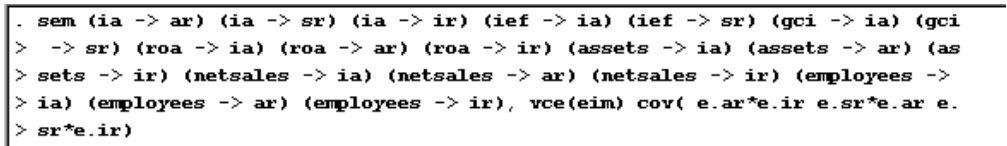 } \\
\hline \multicolumn{7}{|c|}{ Endogenous variables } \\
\hline \multicolumn{7}{|c|}{ Observed: ia ar sr ir } \\
\hline \multicolumn{7}{|c|}{ Exogenous variables } \\
\hline Observed: ief & ci roa asse & netsales & ployees & & & \\
\hline \multirow{3}{*}{\multicolumn{7}{|c|}{$\begin{array}{l}\text { Structural equation model } \\
\text { Bstimation method }=\mathbf{m l} \\
\text { Log likelihood }=\mathbf{- 1 5 0 9 . 6 3 4 2}\end{array}$}} \\
\hline & & & & & & \\
\hline & & & & & & \\
\hline & Coef. & $\begin{array}{c}\text { BIM } \\
\text { Std. Err. }\end{array}$ & $\mathrm{z}$ & $p>|z|$ & [95* Conf. & Interval] \\
\hline \multirow{2}{*}{\multicolumn{7}{|c|}{$\begin{array}{c}\text { Structural } \\
\text { ia }<-\end{array}$}} \\
\hline & & & & & & \\
\hline gci & $\begin{array}{r}-0043018 \\
-.106896\end{array}$ & $\begin{array}{l}.0222461 \\
.0754096\end{array}$ & -1.42 & 0.156 & -.2546961 & .0409041 \\
\hline roa & -.0009201 & .0257975 & -0.04 & 0.972 & -.0514821 & .049642 \\
\hline assets & $2.64 e-10$ & $2.37 e-09$ & 0.11 & 0.911 & $-4.37 e-09$ & $4.90 e-09$ \\
\hline netsales & $-3.75 e-10$ & 2. $79 e-09$ & -0.13 & 0.893 & $-5.85 e-09$ & $5.10 e-09$ \\
\hline employees & $4.08 \mathrm{e}-07$ & $1.85 e-06$ & 0.22 & 0.825 & $-3.21 e-06$ & $4.03 e-06$ \\
\hline _cons & .161542 & .897198 & 0.18 & 0.857 & -1.596934 & 1. 920018 \\
\hline \multicolumn{7}{|l|}{ ar $<-$} \\
\hline ia & -84.14843 & 75.74272 & -1.11 & 0.267 & -232.6014 & 64.30458 \\
\hline roa & 26.15302 & 11.59059 & 2.26 & 0.024 & 3.435874 & 48.87016 \\
\hline assets & 1. $39 \mathrm{e}-06$ & $1.00 e-06$ & 1.39 & 0.165 & $-5.75 e-07$ & 3. $36 \mathrm{e}-06$ \\
\hline netsales & $-1.32 e-06$ & 1. $14 \mathrm{e}-06$ & -1.16 & 0.247 & $-3.55 e-06$ & $9.14 e^{-07}$ \\
\hline employees & -.0013013 & .0008169 & -1.59 & 0.111 & -.0029024 & .0002998 \\
\hline _cons & 3. 04618 & 2.51907 & 1. 21 & 0.227 & -1.891106 & 7. 983465 \\
\hline \multicolumn{7}{|l|}{$s x<-$} \\
\hline ia & -9.084459 & 10.40177 & -0.87 & 0.382 & -29.47156 & 11. 30265 \\
\hline ief & -2.502968 & 1. 14781 & -2.18 & 0.029 & -4.752633 & -.2533017 \\
\hline$g c i$ & 4.810489 & 4. 351589 & 1.11 & 0.269 & -3.718469 & 13.33945 \\
\hline _cons & 99.31495 & 45.99031 & 2.16 & 0.031 & 9.175603 & 189.4543 \\
\hline \multicolumn{7}{|l|}{ ir $<-$} \\
\hline ia & -.0523546 & 4.636959 & -0.01 & 0.991 & -9.140628 & 9.035919 \\
\hline roa & -.9182706 & .7170517 & -1.28 & 0.200 & -2.323666 & .4871249 \\
\hline assets & $-3.68 e-08$ & $6.20 e-08$ & -0.59 & 0.553 & $-1.58 e-07$ & $8.47 e^{-08}$ \\
\hline netsales & $7.16 e^{-08}$ & 7. $03 e-08$ & 1.02 & 0.309 & $-6.63 e-08$ & $2.09 \mathrm{e}-07$ \\
\hline employees & -.0000602 & .0000505 & -1.19 & 0.234 & -.0001592 & .0000388 \\
\hline cons & .2471039 & .1552598 & 1.59 & 0.111 & -.0571997 & .5514074 \\
\hline \multicolumn{7}{|l|}{ Variance } \\
\hline e.ia & .0003827 & .0000902 & & & .0002411 & .0006074 \\
\hline e.ar & 84.90728 & 20.01284 & & & 53.4952 & 134.7644 \\
\hline e.sx & 1.509587 & .3558131 & & & .9511042 & 2.396008 \\
\hline e.ir & .3182056 & .0750018 & & & .200483 & .5050541 \\
\hline \multicolumn{7}{|l|}{$\begin{array}{l}\text { Covariance } \\
\text { e.ar }\end{array}$} \\
\hline e.sx & 2.923826 & 1. 948815 & 1.50 & 0.134 & -.8957813 & 6. 743434 \\
\hline e.ir & 1. 501496 & .9017338 & 1.67 & 0.096 & -.2658702 & 3.268861 \\
\hline Y & & & & & & \\
\hline e.ir & -.1492678 & .1181618 & -1.26 & 0.206 & -.3808607 & .0823252 \\
\hline
\end{tabular}

Source: elaborated by the authors from the data of Tables A.7-A.8 and World Economic Forum, 2014.

Figure A.1. Results of the structural modeling for the general data 


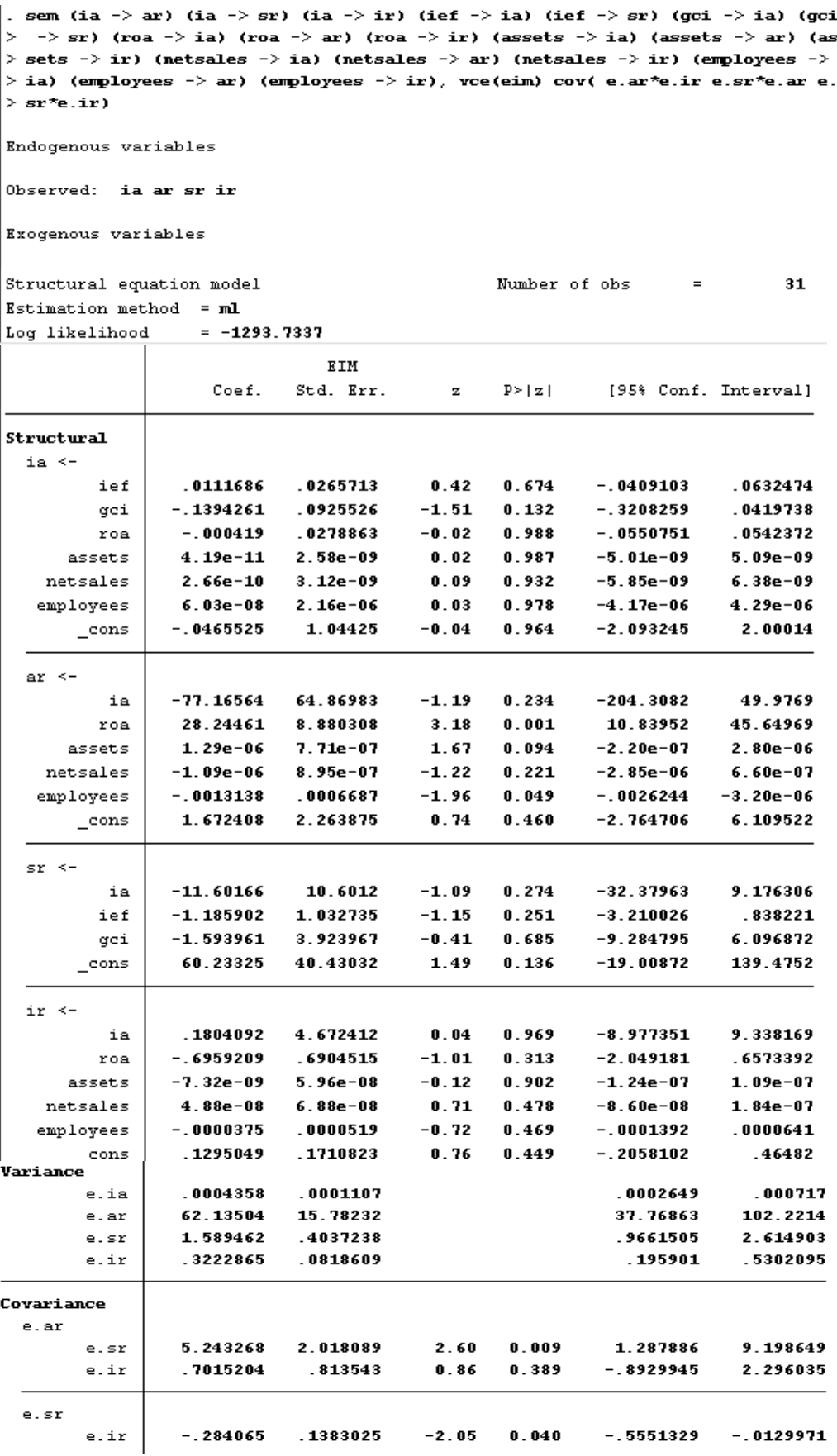

Source: elaborated by the authors from the data of Tables A.7-A.8 and World Economic Forum, 2014.

Figure A.2. Results of the structural modeling for the limited data 